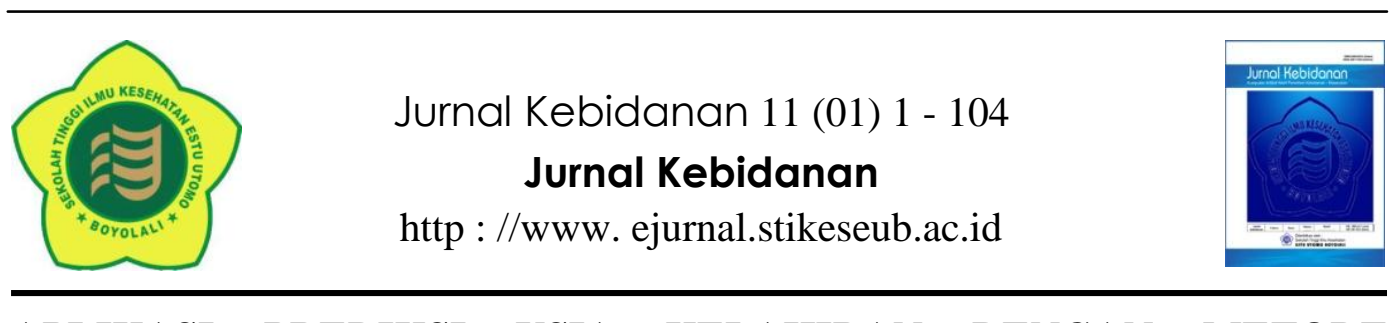

APLIKASI PREDIKSI USIA KELAHIRAN DENGAN METODE

\title{
K-NEAREST NEIGHBOR
}

\author{
Desy Kartika Indahsari ${ }^{1)}$, Yogiek Indra Kurniawan ${ }^{2)}$ \\ ${ }^{1)}$ Informatika/Fakultas Komunikasi dan Informatika, Universitas Muhammadiyah Surakarta \\ ${ }^{2)}$ Teknik Informatika Universitas Jenderal Soedirman \\ E-mail:desykartikaa15@gmail.com,yogiek@unsoed.ac.id.
}

\begin{abstract}
ABSTRAK
Kehamilan dan proses persalinan merupakan suatu proses kehidupan yang terjadi secara alamiah pada setiap makhluk hidup. Usia kelahiran bayi dengan berat badan rendah merupakan salah satu hal yang berpengaruh besar terhadap proses persalinan premature. Dasar tersebut berhubungan dengan banyaknya angka kematian pada kelahiran bayi. Selain itu bayi yang lahir melebihi batas waktu berpengaruh pada proses kelahiran postdate. Aplikasi yang dibuat bertujuan untuk meminimalisir terjadinya hal yang tidak diinginkan dengan mengetahui prediksi pada proses persalinan. Penelitian ini merupakan jenis penelitian klasifikasi dengan metode K-Nearest Neighbor (pendekatan tetangga). Variable yang digunakan merupakan bagian dari faktor penting yang dialami seorang ibu pada saat proses kehamilan, diantaranya: usia ibu hamil, tekanan darah, jumlah bayi, riwayat persalinan, riwayat abortus/kuretase, malnutrisi, penyakit bawaan sebelum hamil dan masalah saat kehamilan. Hasil dari penelitian ini berupa aplikasi prediksi usia kelahiran dengan nilai precicion tertinggi $100 \%$, nilai recall tertinggi $84.905660377358 \%$ dan nilai accuracy tertinggi $96 \%$.
\end{abstract}

Kata Kunci : Aplikasi, Kelahiran, K-Nearest Neighbor, Prediksi.

BIRTH AGE PREDICTION APPLICATION USING K-NEAREST NEIGHBOR METHOD

\begin{abstract}
Pregnancy and giving birth is a natural life process that happen to every human being. Baby's giving birth age with low-weight is one that gave big impact to premature giving birth. These statement relate with many cases of baby's death birth. Beside that, baby birth that exceed normal time give impact to postdate giving birth process.the application made to anticipate and decrease bad thing by knowing the prediction of giving birth process. This research is a type of classification research with the K-Nearest Neighbor method. The variable that used is a part of important factors that happen to a mom in pregnancy process, such as : pregnant mom's age, blood pressure, baby's number,giving birth's story, abortion / curettage's history, malnutrition, congenital disease before pregnant and other problems in a pregnancy. Results of this study is application that can prediction the age of birth with highest precicion value of this application on number $100 \%$, highest recall value on number $84.905660377358 \%$ and highest accuracy value on number $96 \%$.
\end{abstract}

Keywords : Application, Birth, K-Nearest Neighbor, Prediction. 


\section{PENDAHULUAN}

Menurut riset WHO pada setiap tahun angka kelahiran bayi premature diperkirakan mencapai 15 juta, angka tersebut berkisar 5\%-18\% dari angka kelahiran bayi yang berarti lebih dari 1 dalam 10 bayi yang lahir. Secara global premature merupakan penyebab kematian anak yang memiliki usia dibawah 5 tahun dan komplikasi kelahiran premature merupakan penyebab kematian utama pada anak yang memiliki usia di bawah 5 tahun. Penyebab kelahiran secara premature meliputi kehamilan kembar, diabetes, tekanan darah tinggi dan infeksi. Tidak menutup kemungkinan bisa dari faktor genetic. Lebih dari $60 \%$ kelahiran premature di dunia terjadi di Benua Asia Selatan \& Afrika dan kelahiran premature merupakan masalah global. Indonesia menempati peringkat ke-5 dalam angka kelahiran premature dengan jumlah 675.700 bayi dan angka tersebut merupakan $15,5 \%$ dari keseluruhan angka kelahiran bayi di Indonesia (WHO, 2018).

Persalinan premature adalah persalinan yang terjadi dalam masa kehamilan antara 20-37minggu yang disertai dengan berat lahir bayi yang rendah atau kurang dari 2500 gram. Persalinan normal adalah lahirnya bayi yang ada dalam rahim seorang ibu selama 9 bulan dan keluar melalui organ intim seorang wanita tanpa alat bantu apapun. Persalinan ini merupakan persalinan yang paling mulia, dimana bayi dilahirkan hanya dengan tenaga seorang ibu dan bantuan orang yang ahli dalam bidangnya. Persalinan postmature adalah persalinan yang terjadi pada usia kehamilan yang bisa dikatakan lewat bulan atau melebihi hari prediksi lahir yang dan berlangsung lebih dari 42 minggu atau 294hari dalam rahim, dapat dihitung dari hari pertama pada haid terakhir. Postmature dalam istilah lain dapat disebut postterm.

Berdasarkan penjelasan berbagai proses persalinan diatas, maka perlu diketahui apa saja faktor yang dapat mempengaruhi usia kelahiran pada bayi agar dapat meminimalisir hal-hal yang tidak diinginkan sejak dini. Tujuan dari penelitian ini adalah untuk memprediksi usia kelahiran bayi yang dikelompokkan menjadi 3 kategori. Dimana kategori tersebut didasari oleh faktor yang sedang dialami oleh ibu hamil. Tiga kategori usia kelahiran bayi yang digunakan dalam penelitian ini diantaranya adalah premature, normal dan postdate.

Penelitian ini membahas mengenai prediksi usia kelahiran bayi dengan klasifikasi menggunakan metode $\mathrm{K}$ Nearest Neighbor. K-Nearest Neighbor adalah metode pengklasifikasian dari suatu data berdasarkan objek terdekat. Klasifikasi sendiri merupakan sebuah teknik untuk menentukan keanggotaan 
kelompok berdasarkan data-data yang sudah ada. Konsep dasar dari klasifikasi adalah beberapa data yang memiliki struktur data yang mirip akan memiliki klasifikasi yang mirip pula (Bansal, Sharma, \& Goel, 2017). Algoritma KNearest Neighbor telah diterapkan untuk memprediksi kelulusan tepat waktu bagi mahasiswa baru pada STMIK Dipanegara. Data yang digunakan merupakan data alumni dan mahasiswa tahun 2004 sampai dengan 2010 (data pelatihan) dan data mahasiswa tahun 2011 (data uji). Pada kasus tersebut diperoleh nilai akurasi yang cukup tinggi, yaitu 83\% (Mustafa, 2014). Teknik klasifikasi K-Nearest Neighbor juga telah diterapkan pada SMP Negeri 3 Mejayan untuk menentukan siswa berprestasi. Pada studi kasus ini diperoleh tingkat akurasi sebesar $56.57 \%$ dengan perhitungan dari pakar dan $76.67 \%$ dengan perhitungan menggunakan metode K-Nearest Neighbor (Kartika, Santoso, \& Sutrisno, 2017).

Dalam penelitian yang telah dilakukan sebelumnya oleh Naisha dengan judul "Aplikasi Prediksi Usia Kelahiran Bayi Dengan Metode Naïve Bayes" telah didapatkan nilai accuracy tertinggi $78.69 \%$, nilai precision tertinggi $70.14 \%$ dan nilai recall tertinggi $63.64 \%$ (Indraswari \& Kurniawan, 2018). Pada kasus penentuan usia kelahiran dengan algoritma Naïve Bayes diperoleh nilai precision, recall dan accuracy yang lebih tinggi dibandingkan penentuan usia kelahiran dengan algoritma C.45 (Kurniawan, 2018).

Alasan penulis menggunakan motode K-Nearest Neighbor adalah KNearest Neighbor merupakan metode klasifikasi dengan rumus yang sederhana dan mudah untuk diaplikasikan serta memiliki tingkat akurasi yang cukup tinggi. Metode K-Nearest Neighbor sangat tangguh terhadap training data yang memiliki banyak noise dan efektif apabila training datanya besar. Secara umum K-Nearest Neighbor digunakan untuk mengelompokan suatu variable sesuai dengan kategori. Berdasarkan studi kasus ini penulis akan membuat aplikasi dengan bahasa pemrograman PHP dan database MySQL. Penulis berharap dapat membantu mengurangi dan mencegah resiko kematian pada bayi yang diakibatkan oleh usia kelahiran bayi yang terlalu muda (premature) maupun terlalu tua (postdate). Tujuan yang diharapkan adalah dapat mengantisipasinya sejak dini.

\section{METODE}

Metode yang digunakan dalam penelitian adalah metode K-Nearest Neighbor dengan menggunakan data yang telah digunakan pada penelitian sebelumnya. Dari hasil penelitian tersebut diperlukan suatu proses untuk 
menjadikannya data mining. Pada bagian metodologi ini dijelaskan tahapan yang akan dilakukan dalam penelitian mulai dari identifikasi masalah, studi literatur, pengumpulan data, pengolahan data, pembuatan aplikasi, pengujian, analisa hasil dan kesimpulan. Tahapan tersebut ditunjukkan pada Gambar 1.

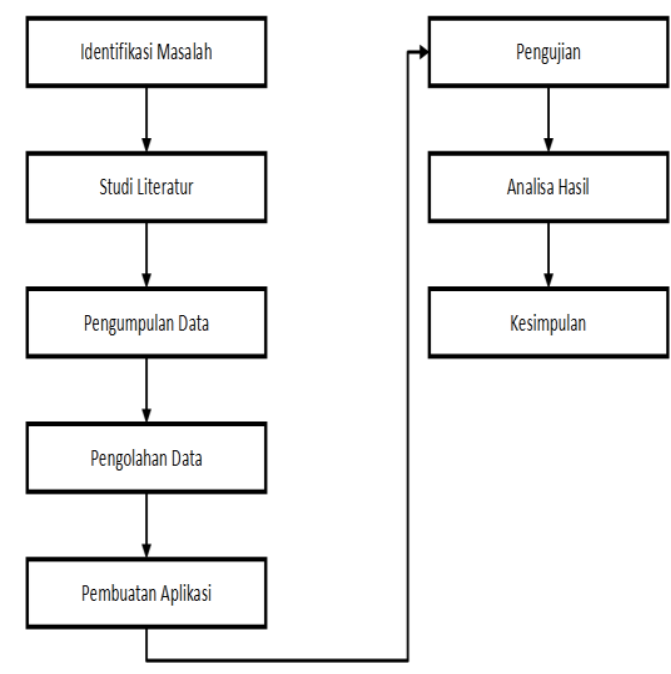

Gambar 1. Metodologi Penelitian

\section{Identifikasi Masalah}

Tahap identifikasi masalah merupakan tahap awal yang bertujuan untuk menentukan masalah yang berkaitan pada kelahiran bayi. Berdasarkan topik masalah yang ada di lapangan maka diperlukan adanya sebuah aplikasi yang dapat membantu dalam menentukan prediksi pada usia kelahiran bayi menjadi 3 kategori usia guna meminimalisir terjadinya hal-hal yang tidak diinginkan. Adapun 3 kategori tersebut yaitu premature, normal dan postdate/ postdatime.

\section{Studi Literatur}

Studi literatur dilakukan dalam pencarian terkait teori, konsep dan metode yang relevan dengan identifikasi masalah. Adapun penjelasan studi literatur yang digunakan penulis dalam acuan pemecahan masalah adalah sebagai berikut:

K-Nearest Neighbor adalah suatu metode algoritma data mining yang melakukan pendekatan untuk mencari kasus dengan cara menghitung kedekatan antara kasus baru dengan kasus lama berdasarkan pada data pembelajaran yang jaraknya paling dekat dengan objek baru. Teknik K-Nearest Neighbor mudah untuk diimplementasikan. Dalam hal ini jumlah data dari tetangga terdekat dinyatakan oleh $k$. Klasifikasi sendiri merupakan teknik data mining yang melihat atribut dari kelompok data yang sudah didefinisikan sebelumnya. Sehingga dapat memberikan klasifikasi pada data baru dengan memanipulasi data yang sudah diklasifikasikan dan menggunakan hasilnya untuk memberikan beberapa aturan. Aturanaturan tersebut dipakai pada data-data baru untuk selanjutnya diklasifikasi (Hardiyanti, 2014).

Metode klasifikasi K-Nearest Neighbor mempunyai beberapa tahapan yang akan ditunjukkan menggunakan flowchart oleh Gambar 2. 


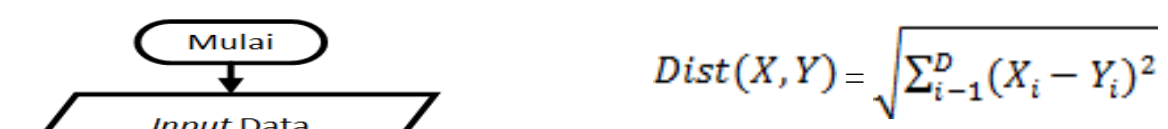

Keterangan:

$$
\begin{aligned}
& X=\text { data contoh } \\
& i=\text { variable data } \\
& \mathrm{Y}=\text { data uji } \\
& \mathrm{D}=\text { variabel data }
\end{aligned}
$$

\section{Pengumpulan Data}

Adapun data yang digunakan untuk penelitian ini didapatkan dari data rekam medik pasien melahirkan di RSUD. Dr. Moewardi Provinsi Jawa Tengah dan Klinik Pratama An-Nisa. Sebanyak 560 data digunakan dalam penelitian ini.

\begin{tabular}{|c|c|c|c|}
\hline variabel & Atribut & Tipe & Keterangan \\
\hline $\mathrm{X} 1$ & Usia Ibu & Polinomial & $\begin{array}{l}\{\text { Kurang }(<20 \text { tahun }), \text { Cukup } \quad(20-35 \\
\text { tahun), Lebih }(>35 \text { tahun })\}\end{array}$ \\
\hline $\mathrm{X} 2$ & Tekanan Darah & Polinomial & $\begin{array}{l}\text { \{Rendah ( } \leq 90 / 70 \mathrm{mmHg}) \text {, Normal } \\
120 / 80-130 / 90 \mathrm{mmHg}) \text {, Tinggi }(\geq 140 / 90 \\
\mathrm{mmHg})\}\end{array}$ \\
\hline $\mathrm{X} 3$ & Jumlah Bayi & Binomial & $\{1,2\}$ \\
\hline $\mathrm{X} 4$ & Riwayat Persalinan & Polinomial & $\begin{array}{l}\text { \{Riwayat Premature, Riwayat } \\
\text { Postmature/Postdate, Riwayat Melahirkan } \\
\text { Usia Normal, Jarak yang singkat dengan } \\
\text { kehamilan sebelumnya ( }<2 \text { tahun), } \\
\text { Persalinan Pertama, Riwayat Persalinan } \\
\text { Caecar, Tidak Ada\} }\end{array}$ \\
\hline $\mathrm{X} 5$ & Riwayat Abortus & Binomial & $\{$ Ya, Tidak $\}$ \\
\hline $\mathrm{X} 6$ & Malnutrisi & Polinomial & $\{$ Kurang, Normal, Lebih $\}$ \\
\hline $\mathrm{X} 7$ & Penyakit Lain & Polinomial & $\begin{array}{l}\text { \{Jantung, Asma, Hipertensi, Anemia, } \\
\text { Diabetes Mellitus, HIV, Tidak Ada }\}\end{array}$ \\
\hline $\mathrm{X} 8$ & $\begin{array}{l}\text { Masalah Saat } \\
\text { Kehamilan Ini }\end{array}$ & Polinomial & $\begin{array}{l}\text { \{Pre-eklamsia Ringan, Pre-eklamsia Berat, } \\
\text { Hipertensi Getasional, Perdarahan, Tidak } \\
\text { Ada }\}\end{array}$ \\
\hline $\mathrm{Y}$ & Usia Kehamilan & Label & $\begin{array}{l}\{\text { Premature }(20-37 \text { minggu), Normal (38- } \\
42 \text { minggu), Postmature/postdate (>42 } \\
\text { minggu }\}\end{array}$ \\
\hline
\end{tabular}
Variabel data yang diambil dijelaskan dalam Tabel 1.

Tabel 1. Penjelasan variable yang digunakan 
Dalam membangun suatu aplikasi diperlukan use case yang dapat menggambarkan penggunaan dan pengelolaan data dalam aplikasi sesuai dengan kebutuhan. Use case dijelaskan pada Gambar 3.

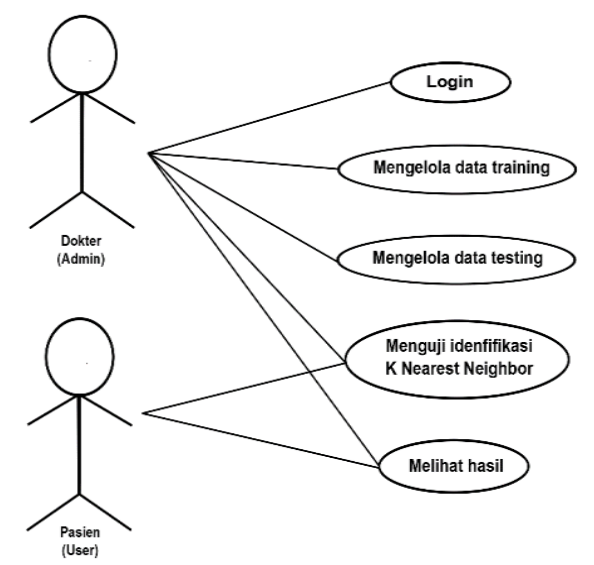

Gambar 3. Use Case Diagram

Keterangan:

Login : Pada langkah ini admin dapat memasukkan userame dan password yang dimiliki.

Mengelola data training : Pada langkah ini admin dapat menambah, mengubah dan menghapus data training yang terdapat pada aplikasi tersebut. Data dapat berupa file dengan ekstensi excel atau data yang dimasukkan melalui form dalam aplikasi.

Mengelola data testing : Pada langkah ini admin dapat menambah, mengubah dan menghapus data testing yang terdapat pada aplikasi tersebut. Data yang dimasukkan dapat berupa file dengan ekstensi excel atau data yang dimasukkan melalui form dalam aplikasi.

Menguji klasifikasi $\quad$ : Pada langkah ini admin serta user dapat menguji K-Nearest Neighbor hasil klasifikasi dengan memasukkan data melalui form dalam aplikasi.

Melihat hasil prediksi $\quad$ : Pada langkah ini admin dan user dapatmelihat hasil pengujian yang mereka masukkan sebelumnya. 


\section{Pengelolaan Data}

Pengelolaan data adalah suatu proses dalam pemrosesan aplikasi, sehingga yang harus dilakukan setelah data dapat menghasilkan hasil mining diperoleh. Pada tahap ini dilakukan yang akurat dan terhindar dari Pembersihan Data atau Data Cleansing. ketidakkonsistenan. Setelah Data Pembersihan Data atau Data Cleansing Cleansing selesai, maka dilakukan berguna untuk membuang data yang uji perhitungan dari data yang telah tidak konsisten dan noise. Pada proses Data Cleansing data disesuaikan dengan atriburt - atribut yang akan dibutuhkan penulis peroleh. Contoh perhitungan menggunakan 5 data training dijelaskan pada Tabel 2.

Tabel 2. Contoh data training (data pelatihan)

\begin{tabular}{|c|c|c|c|c|c|c|c|c|}
\hline Usia & $\begin{array}{c}\text { Tek. } \\
\text { Drh }\end{array}$ & $\begin{array}{c}\text { Jml. } \\
\text { Bayi }\end{array}$ & $\begin{array}{c}\text { R. } \\
\text { Persalinan }\end{array}$ & $\begin{array}{c}\text { R. } \\
\text { Abortus }\end{array}$ & Malnutrisi & $\begin{array}{c}\text { Pny. } \\
\text { Lain }\end{array}$ & $\begin{array}{c}\text { Mslh } \\
\text { Saat } \\
\text { Hamil ini }\end{array}$ & $\begin{array}{c}\text { U. } \\
\text { Kelahiran }\end{array}$ \\
\hline 2 & 2 & 1 & 1 & 2 & 2 & 7 & 5 & 1 \\
\hline 2 & 2 & 1 & 7 & 1 & 2 & 7 & 5 & 2 \\
\hline 1 & 2 & 1 & 1 & 2 & 2 & 7 & 5 & 2 \\
\hline 1 & 1 & 1 & 4 & 1 & 2 & 3 & 5 & 1 \\
\hline 1 & 2 & 1 & 4 & 2 & 3 & 2 & 5 & 1 \\
\hline
\end{tabular}

Contoh perhitungan menggunakan 1 data testing dijelaskan pada Tabel 3.

Tabel 3. Contoh data testing (data uji)

\begin{tabular}{|c|c|c|c|c|c|c|c|c|}
\hline Usia & $\begin{array}{c}\text { Tek. } \\
\text { Drh }\end{array}$ & $\begin{array}{c}\text { Jml. } \\
\text { Bayi }\end{array}$ & $\begin{array}{c}\text { R. } \\
\text { Persalinan }\end{array}$ & $\begin{array}{c}\text { R. } \\
\text { Abortus }\end{array}$ & Malnutrisi & $\begin{array}{c}\text { Pny. } \\
\text { Lain }\end{array}$ & $\begin{array}{c}\text { Saat } \\
\text { Hamil } \\
\text { ini }\end{array}$ & $\begin{array}{c}\text { U. } \\
\text { Kelahiran }\end{array}$ \\
\hline 2 & 2 & 2 & 4 & 1 & 2 & 4 & 5 & $?$ \\
\hline
\end{tabular}

Selanjutnya proses perhitungan dengan metode $K$-Nearest Neighbor dilakukan dengan menggunakan persamaan Euclidian Distance. Proses perhitungan dilakukan kesetiap data lama sehingga nantinya akan menghasilkan nilai jarak sesuai dengan jumlah data lama. Dari perhitungan tersebut diperoleh hasil jarak seperti pada Tabel 4. 
Tabel 4. Hasil perhitungan K-Nearest Neighbor

\begin{tabular}{|c|c|c|c|c|c|c|c|c|c|}
\hline Usia & $\begin{array}{c}\text { Tek. } \\
\text { Drh }\end{array}$ & $\begin{array}{c}\text { Jml. } \\
\text { Bayi }\end{array}$ & $\begin{array}{c}\text { R. } \\
\text { Persali } \\
\text { nan }\end{array}$ & $\begin{array}{c}\text { R. } \\
\text { Abortu } \\
\text { s }\end{array}$ & $\begin{array}{c}\text { Malnutri } \\
\text { si }\end{array}$ & $\begin{array}{c}\text { Pny. } \\
\text { Lain }\end{array}$ & $\begin{array}{c}\text { Mslh Saat } \\
\text { Hamil ini }\end{array}$ & $\begin{array}{c}\text { U. } \\
\text { Kela } \\
\text { hiran }\end{array}$ & $\begin{array}{c}\text { Euclidian } \\
\text { Distance }\end{array}$ \\
\hline 2 & 2 & 1 & 1 & 2 & 2 & 7 & 5 & 1 & 4,472136 \\
\hline 2 & 2 & 1 & 7 & 1 & 2 & 7 & 5 & 2 & 4,358899 \\
\hline 1 & 2 & 1 & 1 & 2 & 2 & 7 & 5 & 2 & 4,582576 \\
\hline 1 & 1 & 1 & 4 & 1 & 2 & 3 & 5 & 1 & 2 \\
\hline 1 & 2 & 1 & 4 & 2 & 3 & 2 & 5 & 1 & 2,828427 \\
\hline
\end{tabular}

$$
\begin{aligned}
\text { Dist } & \left(X_{j} Y\right)=\sqrt{\sum_{i-1}^{D}\left(X_{i}-Y_{i}\right)^{2}} \\
\mathrm{~d}= & \sqrt{\left(x_{1}-X_{2}\right)^{2}+\left(y_{1}-y_{2}\right)^{2}} \\
\mathrm{~d} 1= & \sqrt{\left((2-2)^{2}+(2-2)^{2}+(1-2)^{2}+(1-4)^{2}+(2-1)^{2}+\right.} \\
& \left.(2-2)^{2}+(7-4)^{2}+(5-5)^{2}\right) \\
= & 4,472135955 \\
\mathrm{~d} 2= & \sqrt{\left((2-2)^{2}+(2-2)^{2}+(1-2)^{2}+(7-4)^{2}+(1-1)^{2}+\right.} \\
& \left.(2-2)^{2}+(7-4)^{2}+(5-5)^{2}\right) \\
= & 4,358898944 \\
\mathrm{~d} 3= & \sqrt{\left((1-2)^{2}+(2-2)^{2}+(1-2)^{2}+(1-4)^{2}+(2-1)^{2}+\right.} \\
& \left.(2-2)^{2}+(7-4)^{2}+(5-5)^{2}\right) \\
= & 4,582575695 \\
\mathrm{~d} 4= & \sqrt{\left((1-2)^{2}+(1-2)^{2}+(1-2)^{2}+(4-4)^{2}+(1-1)^{2}+\right.} \\
& \left.(2-2)^{2}+(3-4)^{2}+(5-5)^{2}\right) \\
= & 2 \\
\mathrm{~d} 5= & \sqrt{\left((1-2)^{2}+(2-2)^{2}+(1-2)^{2}+(4-4)^{2}+(2-1)^{2}+\right.} \\
& \left.(3-2)^{2}+(2-4)^{2}+(5-5)^{2}\right) \\
= & 2,828427125
\end{aligned}
$$

Dari keseluruhan hasil perhitungan jarak dengan data training yang berjumlah 5 data, hasil perhitungan diurutkan secara ascending (terkecil hingga terbesar). Dijelaskan dalam tabel 5. Setelah diurutkan, maka dapat dilihat mayoritas klasifikasi yang muncul dari perhitungan jarak yang terkecil atau yang pertama sampai dengan yang kelima. Dijelaskan dalam tabel 6 .

Tabel 5. Hasil urutan Euclidian Distance

$\begin{array}{ccc}\text { Rank } & \text { Euclidian Distance } & \text { Label } \\ 4 & 4,472135955 & 1 \\ 3 & 4,358898944 & 2 \\ 3 & 4,582575695 & 2 \\ 1 & 2 & 1 \\ 1 & 2,828427125 & 1\end{array}$


Tabel 6. Hasil perhitungan $\mathrm{k}=5$

\begin{tabular}{ccc} 
Rank & Euclidian Distance & Label \\
\hline 1 & 2 & 1 \\
2 & 2,828427125 & 1 \\
3 & 4,358898944 & 2 \\
4 & 4,472135955 & 1 \\
5 & 4,582575695 & 2
\end{tabular}

Berdasarkan hasil perhitungan jarak diatas, maka akan didapatkan suatu hasil keputusan:

Premature $: 3$

Normal $: 2$

Postdate/posttime $\quad: 0$

Dapat dilihat pada Tabel.6 mayoritas klasifikasi yang memiliki jumlah paling banyak adalah "1" dimana variable " 1 " merupakan kategori "premature", dan variable "2" merupakan kategori "normal" sehingga rekam medik data ibu hamil yang memiliki nilai sesuai dengan data uji yang telah dihitung diprediksi masuk kedalam kategori "premature".

\section{Pembuatan Aplikasi}

Perancangan aplikasi ini bertujuan untuk membangun suatu aplikasi yang sesuai dengan kebutuhan terlebih dalam sistem informasi medis. Aplikasi dibangun menggunakan bahasa pemrograman PHP dan database MySQL yang berbasis web. Dalam aplikasi ini penulis akan mengimplementasikan algoritma klasifikasi K-Nearest Neighbor.

\section{Pengujian}

Pada tahap pengujian, akan dilakukan sejumlah proses pengujian diantaranya pengujian accuracy, precision dan recall yang dimaksudkan untuk mengetahui tingkat accuracy, precision dan recall terhadap output yang dihasilkan oleh aplikasi.

Accuracy adalah perhitungan yang digunakan untuk mendapatkan nilai hasil dari proporsi jumlah prediksi yang benar (Vafeiadis, Diamantaras, Sarigiannidis, \& Chatzisavvas, 2015). Perhitungan nilai accuracy dirumuskan dalam persamaan 2 berikut:

Accuracy $=\frac{T P+T N}{T P+T N+F P+F N}$

Kemudian Precision adalah perhitungan yang digunakan untuk mencari nilai hasil proporsi kasus dengan hasil diagnose positif. Perhitungan nilai precision dirumuskan dalam persamaan 3 berikut :

$$
\text { Precision }=\frac{T P}{T P+F P}
$$

Sedangkan Recall merupakan model perhitungan yang digunakan untuk mencari nilai hasil proporsi kasus positif yang diidentifikasi dengan benar. Perhitungannilai recall dirumuskan dalam persamaan 4 berikut :

$$
\text { Recall }=\frac{T P}{T P+F N}
$$

Keterangan :
TP: True Positive
FP: False Positive
TN:True Negative
FN:False Negative 


\section{Kesimpulan}

Pada tahap ini akan dirumuskan kesimpulan berdasarkan penelitian yang telah diakukan. Apakah sudah sesuai dengan tujuan dan harapan yang diinginkan atau belum.

\section{HASIL DAN PEMBAHASAN}

\section{Implementasi}

Implementasi dari perancangan ini merupakan sebuah aplikasi yang dapat digunakan untuk memprediksi usia kelahiran bayi. Aplikasi yang dihasilkan merupakan aplikasi pendamping dalam bidang kelahiran. Dalam aplikasi tersebut terdapat 2 aktor yang dapat mengakses aplikasi.

a. Admin

Admin merupakan aktor utama yang memiliki hak akses penuh terhadap aplikasi ini. Untuk dapat mengakses seluruh menu admin diwajibkan untuk login terlebih dahulu dengan mengisi username serta password yang telah dimiliki sebelumnya. Setelah login berhasil admin akan masuk pada halaman utama aplikasi. Pada halaman utama terdapat beberapa menu yang dapat diakses oleh admin, diantaranya data latih (input data latih, input data excel dan lihat data latih), data uji (input data uji, input data excel dan lihat data uji), accuracy, data total (masukkan data total, masukkan data excel dan lihat data total), prediksi usia kelahiran (lakukan prediksi dan lihat prediksi) dan logout.
Pada menu data latih, data uji, data total dan prediksi usia kelahiran admin dapat melakukan berbagai kegiatan yaitu memasukkan data, melihat data yang telah dimasukkan, menghapus data serta memperbarui data. Pada menu accuracy admin dapat melihat berapa nilai precicion, recall dan accuracy yang telah didapat dari hasil perhitungan data yang telah dilakukan. Pada menu data latih (data training) dan data uji (data testing) terdapat sub menu yang dapat digunakan untuk input data latih atau data uji secara manual, input data latih atau data uji dengan mengekspor data dari ekstensi excel dan melihat data latih atau data uji yang telah dimasukkan.

Pada menu accuracy akan ditampilkan nilai hasil perhitungan dari data latih dan data uji yang telah diinputkan. Nilai tersebut akan ditunjukkan pada gambar 4. Hasil Accuray.

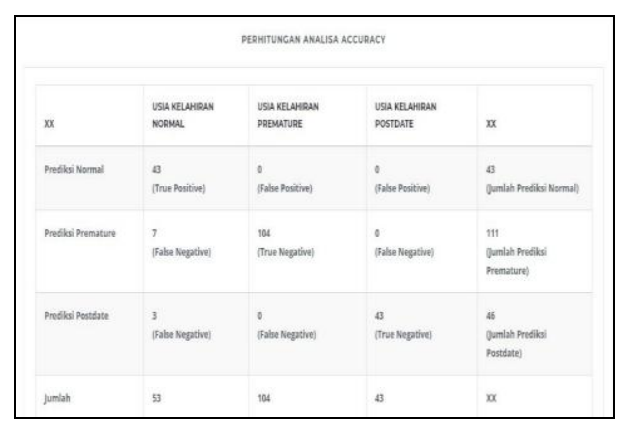




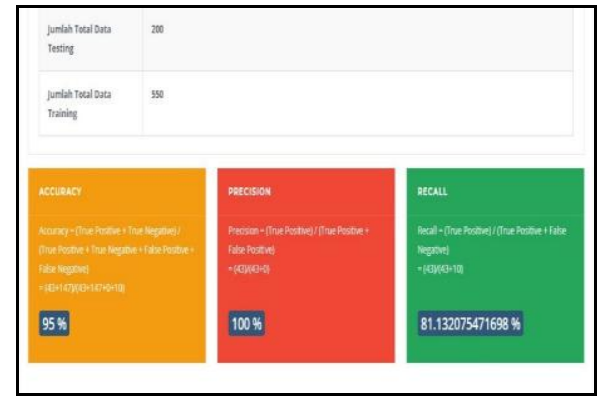

Gambar 4. Hasil Accuracy

Pada menu data total mempunyai tiga sub menu, yaitu masukkan data total, masukkan data excel dan lihat data total. Pada menu prediksi usia kelahiran terdapat dua sub menu yang dapat digunakan yaitu, lakukan prediksi dan lihat prediksi. Dan yang terakhir yaitu logout, dapat digunakan untuk keluar dari halaman admin menuju halaman user.

b. User

User atau pasien merupakan aktor yang memiliki keterbatasan dalam hak akses. User atau pasien dapat mengakses halaman utama tanpa login terlebih dahulu. Hak akses yang dapat dilakukan oleh user yaitu memprediksi usia kelahiran dimana user terlebih dahulu diwajibkan untuk mengisi form yang telah tersedia dalam aplikasi tersebut. Hasil perhitungan menggunakan metode $\mathrm{K}$ -
Nearest Neighbor akan ditampilkan pada halaman hasil akurasi yang akan ditunjukkan pada gambar 5. Form Prediksi.
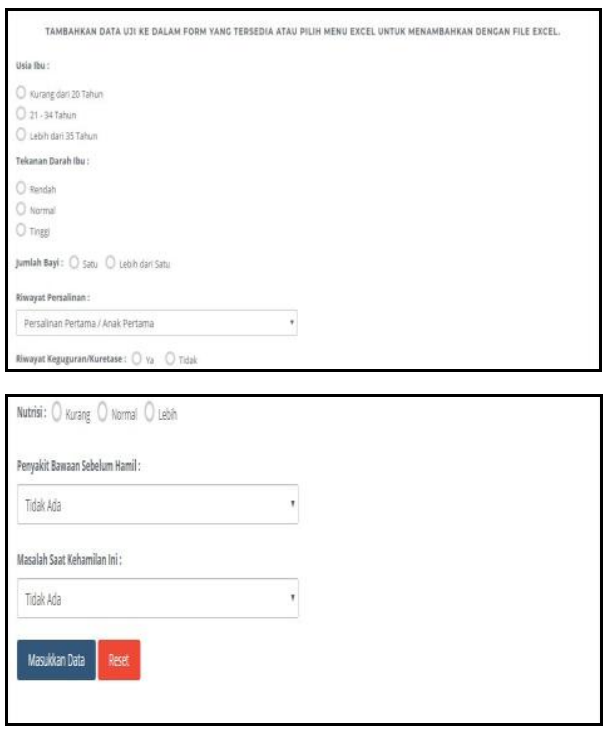

Gambar 5. Form Prediksi

\section{Pengujian}

Pada tahap ini dilakukan pengujian dengan tiga cara. Diantaranya pengujian blackbox, pengujian Algoritma $K$ Nearest Neighbor serta pengujian precicion, recall dan accuracy.

\section{Pengujian Blackbox}

Pengujian blackbox digunakan untuk menguji setiap perintah yang ada didalam aplikasi tersebut, serta memastikan apakah aplikasi yang dibuat sudah dapat berjalan dengan semestinya.

Tabel 7. Pengujian Blackbox

\begin{tabular}{|c|l|l|c|}
\hline Modul & \multicolumn{1}{|c|}{ Input } & \multicolumn{1}{|c|}{ Hasil yang diharapkan } & $\begin{array}{c}\text { Hasil pada } \\
\text { aplikasi }\end{array}$ \\
\hline Login & $\begin{array}{l}\text { Username dan password } \\
\text { benar }\end{array}$ & $\begin{array}{l}\text { Masuk dan dapat mengakses } \\
\text { halaman admin }\end{array}$ & valid \\
\hline Input data & $\begin{array}{l}\text { Memasukkan data dan } \\
\text { seluruh data terisi }\end{array}$ & $\begin{array}{l}\text { Data tersimpan dalam database } \\
\text { dan masuk ke halaman lihat data }\end{array}$ & valid \\
\hline Input data & Memasukkan data dan & Data tersimpan dalam database & valid \\
\hline
\end{tabular}




\begin{tabular}{|c|c|c|c|}
\hline prediksi & seluruh data terisi & $\begin{array}{l}\text { dan masuk ke halaman hasil } \\
\text { prediksi }\end{array}$ & \\
\hline $\begin{array}{l}\text { Import data } \\
\text { excel }\end{array}$ & $\begin{array}{l}\text { Memasukkan data dan } \\
\text { seluruh data terisi }\end{array}$ & $\begin{array}{l}\text { Data tersimpan dalam database } \\
\text { dan muncul review data pada } \\
\text { halaman view excel }\end{array}$ & valid \\
\hline $\begin{array}{l}\text { Mengubah } \\
\text { data }\end{array}$ & $\begin{array}{l}\text { Melakukan perubahan } \\
\text { data dan seluruh data } \\
\text { terisi }\end{array}$ & $\begin{array}{l}\text { Data terubah dan tersimpan } \\
\text { kembali dalam database }\end{array}$ & valid \\
\hline $\begin{array}{l}\text { Menghapus } \\
\text { data }\end{array}$ & $\begin{array}{lr}\text { Menghapus data } & \text { sesuai } \\
\text { dengan data } & \text { yang } \\
\text { diinginkan } & \end{array}$ & $\begin{array}{l}\text { Data yang dipilih akan dihapus } \\
\text { dan tidak ada dalam database }\end{array}$ & valid \\
\hline $\begin{array}{l}\text { Melakukan } \\
\text { prediksi }\end{array}$ & $\begin{array}{l}\text { Mengisi data dan seluruh } \\
\text { data terisi }\end{array}$ & $\begin{array}{l}\text { Menampilkan form untuk } \\
\text { memasukkan data yang akan di } \\
\text { prediksi }\end{array}$ & valid \\
\hline Logout & Keluar dari aplikasi & $\begin{array}{l}\text { Keluar dari sistem dan } \\
\text { menampilkan halaman Login }\end{array}$ & valid \\
\hline
\end{tabular}

\section{Pengujian Algoritma K-Nearest Neighbor}

Pada pengujian Algoritma K-Nearest Neighbor, dilakukan pengujian terhadap hasil yang telah dilakukan dengan sistem. Pengujian ini dilakukan perhitungan secara manual untuk menguji apakah hasil perhitungan dari sistem dapat menghasilkan hasil yang sama dengan hasil perhitungan yang dilakukan secara manual. Pengujian Algoritma K-Nearest Neighbor dilakukan dengan 5 data training dan 1 data testing. Dari hasil yang diperoleh menunjukkan hasil akhir perhitungan yang sama. Hal ini menunjukkan bahwa aplikasi yang dibangun berhasil.

Pengujian Precicion, Recall dan Accuracy

Pengujian ini digunakan untuk mengetahui nilai Precicion, Recall dan Accuracy yang diperoleh dari perhitungan data testing dengan data training yang telah diambil dari keseluruhan data yang berjumlah 560 data.

Tabel 8. Pengujian Precicion, Recall dan Accuracy

\begin{tabular}{|c|c|c|c|c|}
\hline $\begin{array}{c}\text { Data } \\
\text { Training }\end{array}$ & $\begin{array}{c}\text { Data } \\
\text { Testing }\end{array}$ & Precicion & Recall & Accuracy \\
\hline 100 & 200 & $84.313725490196 \%$ & $65.151515151515 \%$ & $84.5 \%$ \\
\hline 150 & 200 & $84.313725490196 \%$ & $64.179104477612 \%$ & $84 \%$ \\
\hline 200 & 200 & $84.313725490196 \%$ & $74.137931034483 \%$ & $88.5 \%$ \\
\hline 250 & 200 & $84.313725490196 \%$ & $75.438596491228 \%$ & $89 \%$ \\
\hline 300 & 200 & $97.727272727273 \%$ & $74.137931034483 \%$ & $92 \%$ \\
\hline 350 & 200 & $100 \%$ & $74.137931034483 \%$ & $92.5 \%$ \\
\hline 400 & 200 & $100 \%$ & $75.438596491228 \%$ & $93 \%$ \\
\hline 450 & 200 & $100 \%$ & $81.132075471698 \%$ & $95 \%$ \\
\hline 500 & 200 & $100 \%$ & $84.905660377358 \%$ & $96 \%$ \\
\hline 550 & 200 & $100 \%$ & $81.132075471698 \%$ & $95 \%$ \\
\hline
\end{tabular}


Tabel 8 menunjukkan bahwa semakin banyaknya jumlah data training yang digunakan dalam pengujian dengan jumlah data testing yang sama maka ratarata nilai precicion, recall dan accuracy yang didapat cenderung semakin tinggi.

\section{Analisa Hasil}

Analisa hasil dapat digunakan untuk memprediksi hasil terkait dengan fungsionalitas dari sistem yang telah dirancang. Aplikasi ini dapat diakses oleh 2 aktor. Yang pertama yaitu seorang admin. Admin dapat mengakses segala menu yang terdapat pada halaman admin. Yang kedua yaitu user atau pasien. User atau pasien hanya dapat melakukan prediksi usia kelahiran tanpa login terlebih dahulu.

Pengujian dilakukan sebanyak 3 kali. Pertama menggunakan pengujian blackbox, dimana seluruh menu yang dibuat dapat berjalan sesuai dengan fungsi yang telah diharapkan. Kedua menggunakan pengujian algoritma $K$ Nearest Neighbor, pada pengujian ini dilakukan dua kali perhitungan yaitu dengan perhitungan manual dan perhitungan dengan sistem. Pada kedua perhitungan didapatkan hasil yang sama, hal itu menunjukkan bahwa sistem telah berhasil. Ketiga menggunakan pengujian precicion, recall dan accuracy, pada pengujian ini didapatkan kesimpulan bahwa semakin banyak nilai training yang digunakan dalam pengujian maka rata-rata nilai yang diperoleh juga semakin tinggi untuk tingkat precicion, recall dan accuracy-nya.

\section{PENUTUP}

Berikut beberapa hasil kesimpulan yang didapat dengan sistem tersebut adalah :

Terdapat dua faktor yang dapat mengakses aplikasi. Admin mempunyai hak akses penuh terhadap aplikasi, sedangkan user hanya mendapatkan akses terbatas. Pengujian blackbox menunjukkan bahwa seluruh perintah telah berjalan sesuai dengan semestinya. Pengujian Algoritma $K$ Nearest Neighbor menunjukkan bahwa perhitungan manual dengan perhitungan sistem menghasilkan nilai yang sama. Pengujian Precicion, Recall dan Accuracy Semakin banyak nilai training yang digunakan dalam pengujian maka rata-rata nilai yang diperoleh cenderung semakin tinggi untuk tingkat precicion, recall dan accuracy-nya.

Jika pasien mempunyai riwayat persalinan Cectio Caesarea (CS) karena berbagai faktor (misal: panggul kecil, tekanan darah tinggi dll) maka dapat di gambarkan kemungkinan untuk persalinan selanjutnya juga akan melahirkan secara Cectio Caesarea (CS). 


\section{DAFTAR PUSTAKA}

Artikel Jurnal.

Bansal, A., Sharma, M., \& Goel, S. (2017). Improved k-mean clustering algorithm for prediction analysis using classification technique in data mining. International Journal of Computer Applications, 157(6), 0975-8887.

Artikel Jurnal

Hardiyanti， S 2014, 'Implementasi Metode Modified K-Nearest Neighbor (MKNN) Pada Penentuan Keminatan Sekolah Menengah Atas (SMA) (Studi Kasus: SMA Negeri 1 Seririt)' Universitas Brawijaya Malang.

Artikel Jurnal

Indraswari, N. R., \& Kurniawan, Y. I. (2018). Aplikasi Prediksi Usia Kelahiran Dengan Metode Naïve Bayes. Simetris: Jurnal Teknik Mesin, Elektro dan Ilmu Komputer, 9(1), 129-138.

Sumber Rujukan dari Website

Kartika, J., Santoso, E., \& Sutrisno, S. (2017). Penentuan Siswa Berprestasi Menggunakan Metode K-Nearest Neighbor dan Weighted Product (Studi Kasus : SMP Negeri 3 Mejayan). Jurnal Pengembangan Teknologi Informasi Dan Ilmu Komputer, 1(5), 352-360. Diambil dari http://j-

ptiik.ub.ac.id/index.php/jptiik/article/view/105

Artikel Jurnal

Kurniawan, Y. I. (2018). Perbandingan Algoritma Naive Bayes dan C. 45

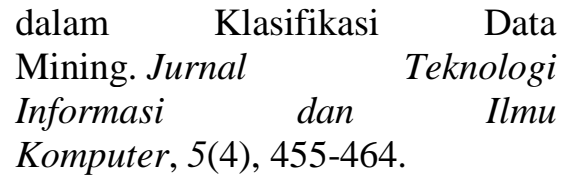

Artikel Jurnal

Mustafa, M. S., \& Simpen, I. W. (2014). Perancangan Aplikasi Prediksi Kelulusan Tepat Waktu Bagi Mahasiswa Baru Dengan Teknik Data Mining (Studi Kasus: Data Akademik Mahasiswa STMIK Dipanegara Makassar). Creative Information Technology Journal, 1(4), 270-281.

Buku

Nughroho, Taufan. (2012). Patologi Kebidanan. Yogyakarta: Nuha Medika.

Artikel Jurnal

Sreemathy, J., \& Balamurugan, P. S. (2012). An efficient text classification using knn and naive bayesian. International Journal on Computer Science and Engineering, 4(3), 392.

Artikel Jurnal

Vafeiadis, T., Diamantaras, K. I., Sarigiannidis, G., \& Chatzisavvas, K. C. (2015). A comparison of machine learning techniques for customer churn prediction. Simulation Modelling Practice and Theory, 55, 1-9.

Sumber Rujukan dari Website

WHO (2018). Preterm Birth. World Health Organization. Tersedia: http://www.who.int/newsroom/fact-sheets/detail/pretermbirth [Diakses: 5 Oktober 2018]. 